\title{
First occurrence of Amblyomma ovale in the State of Rio Grande do Norte, Brazil
}

\author{
Primeira ocorrência de Amblyomma ovale no Estado do Rio Grande do Norte, Brasil \\ Caroline Gracielle Torres Ferreira ${ }^{1 *}$; Ana Carla Diógenes Suassuna Bezerra²; \\ Otávio Valério de Carvalho'; Márcia Rogéria de Almeida ${ }^{3}$; Claudio Mafra ${ }^{3}$
}

${ }^{1}$ Department of Veterinary Medicine, Federal University of Viçosa - UFV, Viçosa, MG, Brazil

${ }^{2}$ Department of Animal Sciences, Federal Rural University of the Semi-Arid - UFERSA, Mossoró, RN, Brazil

${ }^{3}$ Departament of Biochemistry and Molecular Biology, Federal University of Viçosa - UFV, Viçosa, MG, Brazil

Received March 1, 2012

Accepted April 4, 2012

\begin{abstract}
This study aims to report the occurrence of parasitism by Amblyomma ovale (Koch, 1844) in dogs in the municipality of Apodi, Rio Grande do Norte, Brazil. Specimens were identified as being one female and two males of $A$. ovale, besides; the animal was infested by five females of Rhipicephalus (Boophilus) microplus and seven females and three males of $R$. sanguineus. The finding of $A$. ovale confirms results in the literature that these ticks, reported in several species of wild carnivores, can also infect dogs in Brazil. The distribution of this tick species in several Brazilian states has already been confirmed, but this is the first report in the State of Rio Grande do Norte. This finding highlights the risk of the carrying of emerging and re-emerging pathogens to peridomestic hosts are as, either because of the frequency of these ticks in wild environments or the presence of infected wild animals near peridomestic environments, exposing domestic dogs to parasitism by $A$. ovale ticks and, therefore, to agents potentially carried by this ectoparasite.
\end{abstract}

Keywords: Amblyomma, tick, parasitism.

\section{Resumo}

O presente estudo objetiva comunicar a ocorrência do parasitismo por Amblyomma ovale (Koch, 1844) em cáo, no município de Apodi, Rio Grande do Norte, Brasil. Os exemplares foram identificados como sendo uma fêmea e dois machos de $A$. ovale, além destes, o animal estava parasitado por cinco fêmeas de Rhipicephalus (Boophilus) microplus, sete fêmeas e três machos de $R$. sanguineus. O encontro de $A$. ovale confirma os resultados da literatura de que esses carrapatos, relatados em várias espécies de carnívoros silvestres, também podem infestar cães no Brasil. Este carrapato tem sua distribuiçáo confirmada em vários estados brasileiros, sendo este o primeiro relato no Estado do Rio Grande do Norte. Este achado alerta para o risco do carreamento de patógenos emergentes e re-emergentes para regiôes peridomiciliares, seja devido a frequência destes carrapatos em ambientes silvestres ou da presença de animais silvestres parasitados próximos a ambientes peridomiciliares, expondo cáes domésticos ao parasitismo por carrapatos $A$. ovale e, consequentemente, a agentes potencialmente veiculados por este ectoparasito.

Palavras-chave: Amblyomma, carrapato, parasitismo.

Several arthropods that live as ectoparasites on domestic dogs can cause severe dermatitis and also act as pathogen vectors, resulting in disease transmission to animals and humans. Among these

\footnotetext{
${ }^{*}$ Corresponding author: Caroline Gracielle Torres Ferreira

Laboratório de Virologia Molecular Animal - LVMA,

Departamento de Medicina Veterinária, Universidade Federal de Viçosa - UFV,

Av. Peter Henry Rolfs, s/n, CEP 36571-000, Viçosa, MG, Brasil

e-mail: caroline-torres@hotmail.com
}

ectoparasites, ticks have great medical and veterinary importance due to their participation in the transmission of diseases such as babesiosis, hepatozoonosis, ehrlichiosis, borreliosis, and rickettsiosis infections (FÖLDVÁRI; FARKAS 2005).

So far, 870 tick species have been described in the world; they are divided in three families: Ixodidae (680 spp.) and Argasidae (183 spp.), which are distributed in all continents, and Nutallialidae ( $1 \mathrm{sp}$.), which is restricted to Africa (BARROS-BATTESTI et al., 
2006). In Brazil, the fauna of ticks Ixodidae is represented by 61 species, divided into nine genera, with Amblyomma genus being the most numerous (30 spp.), followed by Carios (10 spp.), Ixodes (8 spp.), Ornithodoros (3 spp.) Antricola (3 spp.), Haemaphysalis (3 spp.), Rhipicephalus (2 spp.), Argas (1 sp.) and Dermacentor (1 sp.) (DANTAS-TORRES et al., 2009). Among these, there are many reports about tick species parasitizing dogs in the country.

Concerning their development, the environmental characteristics and diversity of host species in each area are considered crucial for the existence of certain species of ticks in dogs. This study aims to report the finding of parasitism by Amblyomma ovale (Koch, 1844) in dogs in the municipality of Apodi, State of Rio Grande do Norte, Brazil.

In May 2011, 18 ticks were collected from different regions of the body of a male, adult domestic mongrel dog from the rural area of the municipality of Apodi (05 39' 50.4" S and $37^{\circ} 47^{\prime}$ 56.4” W), State of Rio Grande do Norte, Brazil. According to the owner, the ticks were removed manually by twisting them from the skin of the dog that had just died. It was believed that these ticks had contributed as the cause of death since the animal was very weak after infestation. The collected specimens were placed in a glass jar and preserved in alcohol $70 \%$; identification was performed with the aid of a stereomicroscope using the taxonomic keys by Barros-Battesti et al. (2006).

Through external and taxonomic morphological analysis, the specimens analyzed were identified as five females of Rhipicephalus (Boophilus) microplus (Canestrini, 1888), seven females and three males of Rhipicephalus sanguineus (Latreille, 1806), and one female and two males of Amblyomma ovale (Koch, 1844).

Some authors consider this diversity of species as a result of the contact of dogs with different ecosystems, including the sharing of their environment with wild life and, consequently, acquiring mixed infestations (SZABÓ et al., 2001; PEREZ et al., 2008).

In dogs living in urban areas, the tick species most commonly found is $R$. sanguineus, tick originated from the Old World and introduced in Brazil during the colonization period and distributed in all geographic regions of the country since the 1930s (ARAGÃO, 1936). In these urban areas, the availability of habitats for free-living stages of this tick is abundant, since it has the habit of penetrating small holes or cracks in concrete or wooden surfaces. In contrast, in the rural areas, the availability of habitats is limited, concentrated in installations where stray dogs tend to spend a few hours of the day, which contributes to the maintenance of environmental infestations by $R$. sanguineus in these areas (LABRUNA et al., 2001). Moreover, the parasitism by $R$. (B.) microplus in dogs may be related to the possibility of this tick parasitize multiple host species and also due to the access of this domestic animal to cattle pastures, where active forms of $R$. (B.) microplus are often found. This finding was also reported by other authors in similar situations (LABRUNA et al., 2001; SZABÓ et al., 2001; RODRIGUES et al., 2008; FERREIRA et al., 2010).
The finding of $A$. ovale tick in a dog from a rural area in the municipality of Apodi, State of Rio Grande do Norte, as well as the findings described in the literature reporting the presence of different species of ticks parasitizing wild carnivores (GUIMARÃES et al., 2001; RODRIGUES; DAEMON, 2004) and also infesting dogs in other rural areas of the country (LABRUNA et al., 2001; SZABÓ et al., 2001; RODRIGUES et al., 2008), are explained by the free access of dogs to these areas of woods and forests, which was confirmed by the owner of the animal. In fact, it was reported that the dog was often used for hunting activities, thereby assuming risk factors by being exposed to areas inhabited by these ectoparasites.

The ticks $A$. ovale present a wide geographical distribution in several countries of Central and South America, spanning from Argentina to southern Mexico, parasitizing various hosts, mainly representatives of the Order Carnivora (GUGLIELMONE et al., 2003; BARROS-BATTESTI et al., 2006). In Brazil, the existence of these ticks has been reported in the states of Amazonas, Ceara, Góias, Minas Gerais, Mato Grosso do Sul, Pará, Parana, Santa Catarina and Sao Paulo (ARAGÃO; FONSECA, 1961; GUIMARÂES et al., 2001; SERRA-FREIRE et al., 2011); the one described herein is the first case reported in the State of Rio Grande do Norte.

As described in the taxonomic key by Barros-Battesti et al. (2006), the analyzed specimens of $A$. ovale presented hypostome $3 / 3$; distinct marginal groove, subsequently limiting all festoons; coppery brown shield with greenish spots (Figure 1a, c); leg I with two contiguous spines, acute, and as long as the length of the thigh, the outer leg being slightly bent out and slightly longer than the internal one (Figure 1b, d), covering both articulate follows.

Thus, according to Labruna (2004), ticks can act as vectors of pathogens and may also exert various deleterious effects to its host, such as anemia and anorexia, both caused by massive infestation; increased predisposition to other diseases, given by the immunosuppressive toxins present in the saliva of the tick, or secondary infection by bacteria or screw worm infestation on the site of attachment of ticks; framework of ascending paralysis, caused by neurotropic toxin, inoculated through the saliva; death by an exacerbation of the effects cited above, or all of them. Obviously, these effects will vary according to tick species and geographic area; however, they corroborate the findings reported by the owner of the animal in this study.

Herein we have presented and discussed this finding of potential importance in the dispersion and maintenance of various diseases transmitted by ticks with their vertebrate hosts, representing a risk to the health and welfare of domestic animals and humans (DANTAS-TORRES et al., 2010; SERRA-FREIRE et al., 2011). These findings pointed out the possibility of the carrying of emerging and re-emerging pathogens to dwellings where pets frequent wild environments, exposing themselves to parasitism by tick, endangering both the local human and canine populations. 

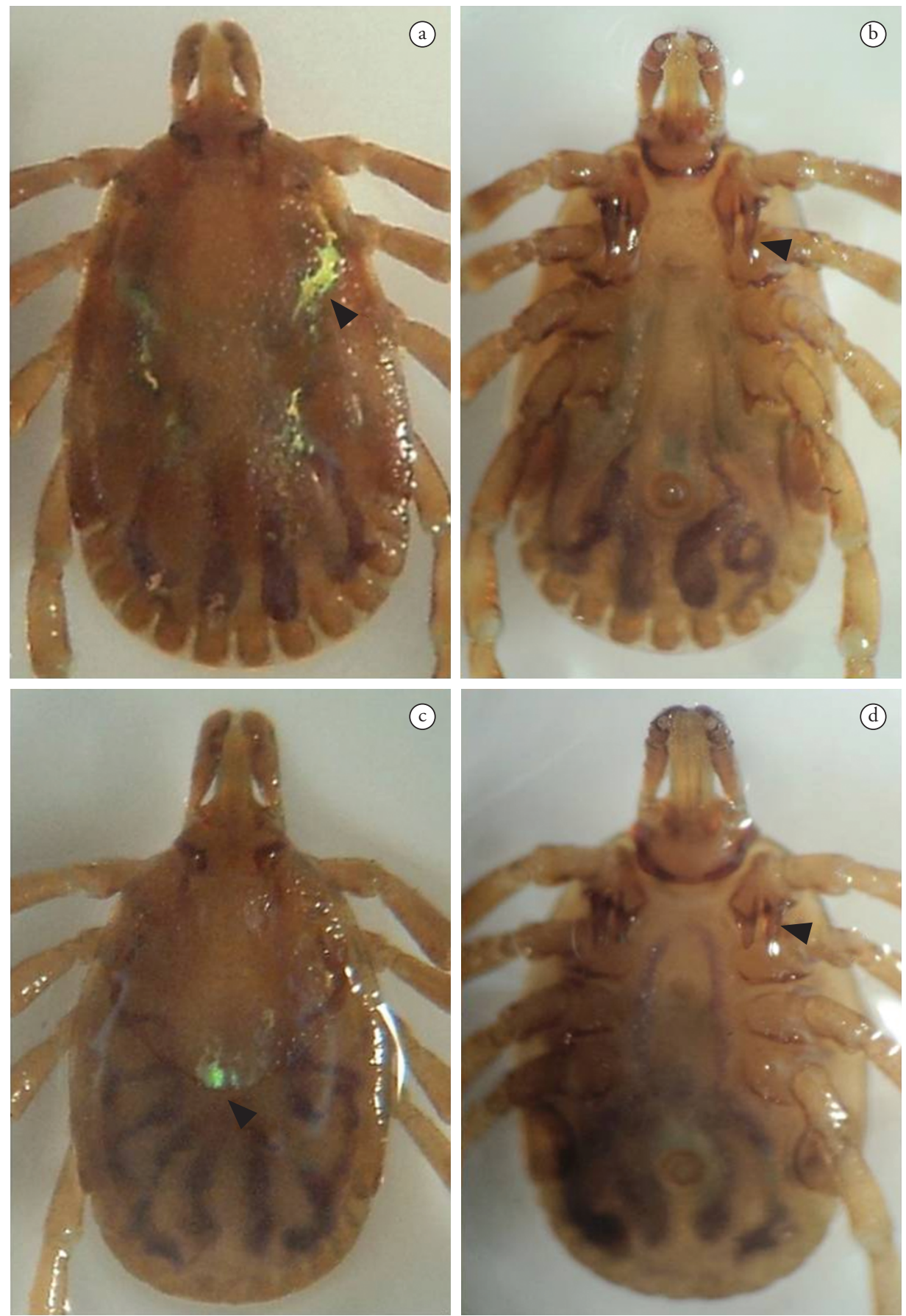

Figure 1. a) male dorsal. b) male ventral. c) female dorsal. d) female ventral. Specimen showing taxonomic characteristics of Amblyomma ovale, as taxonomic key of Barros-Battesti et al. (2006), featured in letter a and c, allowing the visualization of a shield coppery brown with a greenish spots; $\mathrm{b}$ and $\mathrm{d}$. Thighs I with two long spines, the outer slightly curved outward and slightly longer than the internal.

\section{References}

Aragão H. Ixodidas brasileiros e de alguns paizes limitrophes. Mem Inst Oswaldo Cruz 1936; 31(4): 759-843. http://dx.doi.org/10.1590/ S0074-02761936000400004

Aragão H, Fonseca F. Notas de Ixodologia IX. O complexo Ovale do gênero Amblyomma. Mem Inst Oswaldo Cruz 1961; 59(2): 131-
148. PMid:13861961. http://dx.doi.org/10.1590/S007402761961000200002

Barros-Battesti DM, Arzua M, Bechara GH. Carrapatos de importância médico veterinária da região neotropical: um guia ilustrado para identificação de espécies. São Paulo: Vox, ICTTD-3, Butantan; 2006.

Dantas-Torres F, Ferreira DRA, Melo LM, Lima PCP, Siqueira DB, Rameh-de-Albuquerque LC, et al. Ticks on captive and free-living wild 
animals in northeastern Brazil. Exp Appl Acarol 2010; 50(2): 181-189. PMid:19693679. http://dx.doi.org/10.1007/s10493-009-9296-5

Dantas-Torres F, Onofrio VC, Barros-Battesti DM. The ticks (Acari: Ixodida: Argasidae, Ixodidae) of Brazil. Syst Appl Acarol 2009; 14: 30-46.

Ferreira CGT, Bezerra ACDS, Ahid SMM. Ectoparasitas de cães do município de Apodi, Rio Grande do Norte. Pubvet 2010; 4(14): 804.

Földvári G, Farkas R. Ixodid tick species attaching to dogs in Hungary. Vet Parasitol 2005; 129(1-2): 125-131. PMid:15817212. http://dx.doi. org/10.1016/j.vetpar.2004.11.032

Guglielmone AA, Estrada-Peña A, Keirans JE, Robbins RG. Ticks (Acari: Ixodida) of the Neotropical Zoogeographic region. Atalanta: Houten; 2003.

Guimarães JH, Tucci EC, Barros-Battesti DM. Ectoparasitos de importância veterinária. São Paulo: Plêiade; 2001.

Labruna MB. Carta Acarológica. Rev Bras Parasitol Vet 2004; 13(S1): 199 202.

Labruna MB, Souza SLP, Guimarães Junior JS, Pacheco RC, Pinter A, Gennari SM. Prevalência de carrapatos em cães de áreas rurais da região norte do Estado do Paraná. Arq Bras Med Vet Zootec 2001; 53(5): 553-556. http://dx.doi.org/10.1590/S0102-09352001000500007
Perez CA, Almeida AF, Almeida A, Carvalho VHB, Balestrin DC, Guimarães MS, et al. Carrapatos do gênero Amblyomma (Acari: Ixodidae) e suas relaçóes com os hospedeiros em área endêmica para febre maculosa no Estado de São Paulo. Rev Bras Parasitol Vet 2008; 17(4): 210-217. Pmid:19265580.

Rodrigues AFSF, Daemon E. Ixodídeos e sifonápteros em Cerdocyon thous L. (Carnivora, Canidae) procedentes da zona da mata mineira, Brasil. Arq Inst Biol São Paulo 2004; 71(3): 371-372.

Rodrigues DF, Daemon E, Rodrigues AFSF. Caracterizaçáo da populaçáa de ectoparasitos em cães de núcleos de expansão urbana de Juiz de Fora, Minas Gerais, Brasil. Rev Bras Parasitol Vet 2008; 17(4): 185-188. Pmid:19265575.

Serra-Freire NM, Sena LMM, Borsoi ABP. Parasitismo humano por carrapatos na Mata Atlântica, Rio de Janeiro, Brasil. EntomolBrasilis 2011, 4(2): 67-72.

Szabó MPJ, Cunha M, Santos AP, Vicentini F. Ticks (Acari: Ixodidae) associated with domestic dogs in Franca region, São Paulo, Brazil. Exp Appl Acarol 2001; 25(10-11): 909-916. PMid:12455880. http://dx.doi. org/10.1023/A:1020433003028 